\title{
Introduction to the Symposium
}

\section{Inflation Targeting in Emerging Economies: Prerequisites, Policies and Outcomes}

\author{
DAVID M KEMME \\ Department of Economics, University of Memphis, Memphis, TN 38152, USA. \\ E-mail:dmkemme@memphis.edu
}

The creation and maturation of financial institutions in transition and emerging economies has been of central importance in their economic development over the last decade. Because policies are institution dependent, fiscal and monetary policy options were limited by the lack of supporting institutions until the mid-1990s. However, over the last decade institutions have developed sufficiently to allow greater flexibility in policy. In particular, we focus on monetary policy options that became available as Soviet-type monobanks became modern central banks and financial institutions developed. While different countries took slightly different paths at different points in time, a common evolution of monetary policy is evident among the successful transition and emerging economies. Typically in transition economies, like Poland, the Czech Republic and Hungary, the monetary authorities initially adopted a hard peg - a fixed exchange rate, or heavily managed exchange rate, to provide a highly visible nominal anchor. In reality there was little choice. The nominal anchor was not adopted to raise output and employment, but to limit hyperinflation or near hyperinflation.

Given the underdevelopment of the banking systems and the lack of meaningful monetary data in the early 1990s, targeting a domestic monetary aggregate or even a price level or inflation rate was not feasible. Targeting the exchange rate proved effective, however, as the central European countries brought extremely high inflation (over $100 \%$ ) down to very high (over $10 \%$ ). But, with rapid domestic structural economic changes a fixed nominal exchange rate could not be maintained. An intermediate exchange rate regime was typically adopted, coupled with targeting some monetary aggregate. 
For most countries, further reducing inflation proved difficult when monetary authorities targeted money with unstable money demand.

During this same period monetary authorities in more developed industrial economies began implementing inflation forecast targeting, beginning with New Zealand in 1990. ${ }^{1}$ While money and exchange rate targeting seeks to provide price stability through targeting intermediate variables, inflation targeting involves targeting a forecasted value of inflation. Typically the central bank commits to a specific numerical target, a point or range, for the 1 year rate of inflation and this, over a specific horizon, becomes the intermediate target of monetary policy. This single objective then conveys to the public that price stability is the critical objective of central bank policy and also communicates exactly what the bank means by price stability. With the adoption of inflation forecast targeting comes the abandonment of a fixed or managed exchange rate. The currency is allowed to float freely, or with limited intervention to limit excessive volatility. Emerging and transition economies soon followed the lead of the earliest adopters of inflation targeting: New Zealand, Canada, the UK and Australia. Among the emerging economies adopting inflation targeting are those countries considered in this symposium: the Czech Republic in 1998, Poland in 1999, Hungary in 2001, Armenia and Romania in 2005 and Turkey in 2006. The analysis in the symposium indicates that adopting the new policy regime has not been without difficulties, but the new regime has been effective in providing a framework for lowering inflation without sacrificing economic growth. ${ }^{2}$

There are several prerequisites for both the adoption of inflation targeting and the successful operation of the policy regime identified in the literature, although the degree to which they must be fulfilled is certainly arguable. First, a strong fiscal position, or lack of fiscal dominance appears essential. In the case of transition economies the massive restructuring of the economies, privatisation and the creation of social safety nets led to fiscal imbalances that took years to diminish and stabilise at sustainable levels. Only toward the end of the 1990s was monetary policy not dominated by fiscal considerations. Second, a low level of dollarisation and stable or predictable capital inflows enhances the probability of successful inflation

\footnotetext{
${ }^{1}$ As of mid-2005, 21 countries were identified as inflation targeters with several more adopting the policy since then. See IMF (2005). See Jonas and Mishkin (2005) for an early review of central European transition economies.

${ }^{2}$ There are many analyses which indicate that inflation targeting has reduced inflation overall, but sceptics argue that other monetary policy regimes may have been equally effective given that central banks were more able and more diligent in implementing their policies. This remains an open question.
} 
targeting. In many countries very high rates of inflation led to the substitution away from the domestic currency toward dollars or other more stable foreign currencies. Further, highly variable capital inflows due to privatisation, such as in the Czech case, or remittances from abroad in the Armenian case, often require measures to sterilise these flows. Third, appropriate financial institutions including well-developed commercial banking, securities markets for open market operations and an independent central bank are necessary, but perhaps to varying degrees. Clearly the monetary authority, independent or not, must be willing and able to make a commitment to an inflation target and have the credibility of the public in order for the policy to be effective. Without well-developed financial markets, the instruments of monetary policy are limited and implementation remains awkward. Instruments are then generally limited to reserve requirement changes and the use of standing facilities, thus limiting the monetary authority's ability to 'fine tune' policy. If the central bank does not have a clear mandate for price stability, public credibility may not be sufficient for the success of the policy regime. Fourth, given sufficiently developed institutions the monetary policy transmission mechanism must be understood and predictable. The link between instruments and inflation outcomes should be understood and form the basis for the forecasting of inflation by central bank staff. These forecasts provide the basis for policy deliberations and, therefore, the technical capabilities of the central bank, both in understanding the monetary transmission mechanism and the ability to forecast inflation are essential prerequisites. Fifth, inflation targeting will be more likely to succeed if there are no other nominal anchors or central bank policy objectives that may conflict with actions to attain the inflation target. A desire to maintain an exchange rate band, as in Hungary, or not completely abandoning the targeting of monetary aggregates, as in Armenia, or both in the case of Romania, has slowed the public's understanding of the policy and perhaps limited the public's belief in the bank's commitment to price stability. Sixth, along with the abandonment of all other nominal anchors and the clear priority of price stability as the overriding goal, the bank must implement monetary policy actions transparently, communicate these actions to the public and be able to explain deviations of inflation outcomes from targets effectively with appropriate and expected changes in policies to correct these deviations. Each of these factors, either the extent to which they are a prerequisite and have been satisfied or the extent to which they are found deficient and have influenced the success of monetary policy after the implementation of inflation targeting, is discussed or analysed in detail in the papers of this symposium. 
The papers are both descriptive and analytical. The authors, in each case, describe the development of monetary policy for each country and conclude that the prerequisites have been met, at varying times and with varying degrees of difficulty. Then they proceed to analyse the effectiveness of policies. Banaian et al. review the development of monetary policy in Armenia, estimate a central bank reaction function and provide counter factual scenarios that suggest that monetary policy may have been too tight in the late 1990s. Orlowski reviews the inflation targeting policies of the Czech Republic, Hungary and Poland, each somewhat unique. He argues that accession to the European Union (EU) would now best be served if monetary policy targets not inflation per se, but the EU-domestic economy inflation differential. Akyurek and Kutan focus on the Central Bank of Turkey's behaviour in 2002-2006, when the bank moved from implicit to explicit inflation targeting. Here, as fiscal reforms and fiscal discipline developed, the central bank was able to pursue price stability more single-mindedly, hence enhancing its own credibility and the effectiveness of its policy. However, while inflation has been dampened, external shocks in 2006-2007 continue to test the monetary authorities.

Returning to the case of Poland, where inflation targeting has been successfully implemented and inflation has stabilised at low levels, Maliszewski examines a more subtle but critical issue, the National Bank of Poland's (NBP) marginal credibility, or the ability of the bank to influence public expectations by means of policy announcements. Using Bayesian methods to analyse survey data on inflation expectations, forecasts based on macroeconomic data and the central bank's inflation target, he concludes that the credibility of NBP inflation targets after the introduction of inflation targeting was quite high, contributing to the policy's success. On the other hand for Romania, the implementation of inflation targeting and the National Bank of Romania's (NBR) credibility is found lacking by Gabor. She examines the development of monetary policy in Romania, emphasising the contradictions between domestic economic conditions and external factors that limit the scope of the NBR's options. While the NBR has announced inflation targeting, she feels the bank is still overly concerned with moderating real exchange rate appreciation and interest rate smoothing and has not sufficiently removed excess liquidity from the banking system for the policy to be considered fully implemented. Overall, the symposium papers provide ample evidence of both the potential benefits of the adoption of inflation forecast targeting by emerging economies as well as the difficulties in meeting the essential prerequisites for success. 
DM Kemme

Introduction to the Symposium

420

\section{REFERENCES}

International Monetary Fund. 2005: Does inflation targeting work in emerging markets? World Economic Outlook: Building Institutions, September 2005. pp. 161-186, Washington, DC: International Monetary Fund.

Jonas, J and Mishkin, FS. 2005: Inflation targeting in transition economies: Experiences and prospects. In: Bernanke, BS and Woodford, M (eds). The Inflation Targeting Debate. Chicago: University of Chicago Press, pp. 353-413. 